\title{
Silase Komplit Pelepah Kelapa Sawit dan Indigofera sp. dengan Probiotik MOIYL Terhadap Performa Sapi PO
}

\section{Complete Silage of Oil Palm Fronds and Indigofera sp. with MOIYL Probiotics on the Performance of Ongole Breeds}

\author{
Mulya Fauzia ${ }^{1}$, Yunilas ${ }^{1}$, dan Iskandar Sembiring ${ }^{1}$ \\ 'Program Studi Peternakan, Fakultas Pertanian, Universitas Sumatera Utara \\ Jl. Prof. Dr. A. Sofyan No. 3 Kampus USU Medan 20155 \\ yunilas11@yahoo.co.id
}

\begin{abstract}
Diterima : 02 Februari 2019
Disetujui : 20 Februari 2019

Diterbitkan : 22 Februari 2019
\end{abstract}

\begin{abstract}
Abstrak: Tujuan penelitian ini adalah untuk mengetahui pengaruh silase komplit pelepah kelapa sawit dan Indigofera sp. menggunakan probiotik MOIYL (mikroorganisme indigenous YL) terhadap performa Sapi Peranakan Ongole. Metode penelitian menggunakan rancangan acak lengkap (RAL), 4 perlakuan dengan 2 ulangan. Perlakuan meliputi $P_{1}=20 \%$ Silase Komplit dengan probiotik MOIYL $+80 \%$ Konsentrat, $P_{2}=40 \%$ Silase Komplit dengan probiotik MOIYL $+60 \%$ Konsentrat, $P_{3}=60 \%$ Silase Komplit dengan probiotik MOIYL $+40 \%$ Konsentrat, $P_{4}=80 \%$ Silase Komplit dengan probiotik MOIYL $+20 \%$ Konsentrat. Parameter yang diamati adalah konsumsi ransum, pertambahan bobot badan, dan konversi ransum. Hasil penelitian menunjukkan bahwa pemberian silase komplit berbasis pelepah kepala sawit dan Indigofera sp. menggunakan probiotik MOIYL memberikan pengaruh yang sangat nyata $(P<0.01)$ terhadap konsumsi pakan, pertambahan bobot badan, dan konversi ransum. Silase komplit berbasis pelepah kelapa sawit dan Indigofera sp. menggunakan probiotik MOIYL dapat meningkatkan konsumsi pakan, pertambahan bobot badan dan menurunkan konversi ransum. Penggunaan silase komplit yang semakin tinggi dapat menurunkan penggunaan bahan pakan konsentrat seperti dedak padi, bungkil kedelai dan bungkil inti sawit, yang berpengaruh terhadap efisiensi ransum.
\end{abstract}

Kata Kunci: Performa, Probiotik MOIYL, Silase komplit.

Abstract: The purpose of this study was to determine the effect of complete silage of oil palm fronds and Indigofera sp. using probiotics MOIYL (microorganisms of indigenous YL) on the performance of Ongole Breeds. The research method used a completely randomized design (CRD), 4 treatments with 2 replications. Treatment includes $P_{1}=20 \%$ Silase Complete with probiotics MOIYL $+80 \%$ Concentrate, $P_{2}=40 \%$ Silase Complete with probiotics MOIYL $+60 \%$ Concentrate, $P_{3}=60 \%$ Silage Complete with probiotics MOIYL $+40 \%$ Concentrate, $P_{4}=$ $80 \%$ Complete Silage with probiotics MOIYL + $20 \%$ Concentrate. The parameters observed were ration consumption, body weight gain, and ration conversion. The results of the study showed that the supply of complete oil palm head midrib silage and Indigofera sp. using probiotics MOIYL had a very significant effect $(P<0.01)$ on feed consumption, body weight gain, and feed conversion. Complete palm oil-based silage and Indigofera sp. using probiotics MOIYL can increase feed consumption, increase body weight and reduce feed conversion. The higher use of complete silage can reduce the use of concentrated feed ingredients such as rice bran, soybean meal, and palm kernel cake, which influence feed efficiency.

Keywords: Complete silage, Performance, Probiotic MOIYL.

\section{Pendahuluan}

Ketersediaan pakan merupakan kendala utama yang dihadapi oleh peternak sapi pada umumnya. Hal ini sangat dirasakan oleh peternak terutama pada musim kemarau. Ketersediaan pakan ini juga semakin dipersulit dengan semakin menyempitnya areal penggembalaan ternak, sawah dan kebun dimana pada lokasi inilah sebagian sumber pakan ternak ruminansia diperoleh.
Pemenuhan kebutuhan konsumsi ternak dengan menggunakan bahan pakan yang berasal dari limbah perkebunan seperti pelepah kelapa sawit serta hasil samping industri seperti bungkil inti sawit dan molases dapat dijadikan sebagai bahan pakan.

Pelepah daun kelapa sawit merupakan hasil sampingan dari pemanenan buah kelapa sawit. Bila dilihat dari segi ketersediaannya maka pelepah dan daun kelapa sawit sangat potensial digunakan sebagai 
pakan ternak. Pelepah kelapa sawit dapat digunakan sebagai sumber pengganti hijauan atau dapat diberikan dalam bentuk silase yang dikombinasikan dengan bahan lain [1].

Tanaman leguminosa pohon telah dikenal memiliki potensi sebagai sumber pakan berkualitas tinggi, terutama selama musim kering dimana ketersediaan hijauan rumput menurun tajam. Salah satu jenis tanaman leguminosa pohon yang belum banyak dieksplorasi adalah Indigofera sp. Indigofera sp. merupakan jenis leguminosa yang kaya akan protein, kalsium dan fosfor. Namun kendala dalam pemanfaatan indigofera sp sebagai pakan adalah tumbuhan ini kurang disukai ternak sehingga belum banyak direkomendasikan sebagai pakan ternak [2]. Pemanfaatan tanaman Indigofera sp. pada pakan sapi potong dapat diberikan dengan beberapa teknologi diantaranya pemberian tanaman Indigofera sp. segar dicampur dengan rumput lapang atau jenis rumput yang diintroduksi.

Pengolahan pakan menjadi silase dapat melibatkan mikroba lokal baik mikroorganisme indigenous maupun endogenous guna mengatasi permasalahan rendahnya kualitas pakan serta kecernaannya. Untuk meningkatkan konsumsi dan kecernaan pada pelepah daun kelapa sawit dapat dilakukan dengan proses pembuatan silase komplit menggunakan mikroorganisme dan tanaman legum. Salah satu teknologi pengolahan pakan yang dapat dilakukan adalah dengan metode pembuatan silase.

Mikroorganisme Lokal Indigenous merupakan mikroorganisme yang dieksploitasi dari substratnya sendiri yang memiliki kemampuan tinggi dalam mendegradasi serat [3]. Probiotik MOIYL mengandung bakteri, fungi dan yeast berupa Bacillus sp. YLB1, Trichoderma sp. YLF8 dan Saccharomyces sp. YLY3 [4].

Pemenuhan kebutuhan nutrisi ternak dalam proses produksinya membutuhkan konsentrat. Dimana dengan keberadaan konsentrat dalam pakan membantu mempercepat proses penggemukan. Penggunaan konsentrat yang selama ini dilakukan peternak mendapat beberapa kendala dalam memperolehnya misal dari harga yang relatif mahal dan tempat untuk memperolehnya yang jauh.

Berdasarkan uraian di atas penulis berkeinginan melaksanakan penelitian mengenai pengaruh silase komplit berbasis pelepah kelapa sawit dan legum Indigofera sp. dengan menggunakan probiotik MOIYL terhadap performa Sapi Peranakan Ongole dan dapat menurunkan penggunaan konsentrat serta meningkatkan pendapatan peternak.

\section{Materi dan Metode}

\subsection{Waktu dan tempat pelaksanaan}

Penelitian dilaksanakan pada bulan Maret sampai Mei 2018, di Desa Dolok Kataran Kecamatan
Dolok Batu Nanggar Kabupaten Simalungun, Sumatera Utara.

\subsection{Alat dan bahan}

Kandang 8-unit yang dilengkapi dengan tempat pakan dan tempat minum untuk masing-masing sapi serta perlengkapan kandang lain seperti sekop, kereta sorong, karung dan sebagainya. Chopper sebagai alat pencincang pelepah kelapa sawit dan Indigofera sp., mixer sebagai alat pencampuran dalam pembuatan silase komplit. Drum sebagai wadah silase komplit. Timbangan bahan pakan untuk menimbang pakan sapi. Alat tulis untuk mencatat data. Kamera sebagai alat dokumentasi.

Bahan yang digunakan adalah Sapi PO jantan umur 1,5 tahun dengan bobot badan awal 200,22+3,04 kg sebagai objek penelitian sebanyak 8 ekor. Bahan pakan yang diberikan terdiri dari pelepah kelapa sawit, Indigofera sp., dedak padi, bungkil inti sawit, bungkil kedelai, molases, urea, garam, mineral dan silase komplit menggunakan Probiotik MOIYL, dapat dilihat pada Tabel 1 dan kandungan nutrisi ransum perlakuan pada Tabel 2.

\subsection{Metode penelitian}

Penelitian menggunakan rancangan acak lengkap 4 perlakuan dengan 2 ulangan. Adapun perlakuan penelitian sebagai berikut:

$$
\begin{aligned}
\mathrm{P}_{1}= & 20 \% \text { Silase Komplit menggunakan Probiotik } \\
& \text { MOIYL }+80 \% \text { Konsentrat } \\
\mathrm{P}_{2}= & 40 \% \text { Silase Komplit menggunakan Probiotik } \\
& \text { MOIYL }+60 \% \text { Konsentrat } \\
\mathrm{P}_{3}= & 60 \% \text { Silase Komplit menggunakan Probiotik } \\
& \text { MOIYL }+40 \% \text { Konsentrat } \\
\mathrm{P}_{4}= & 80 \% \text { Silase Komplit menggunakan Probiotik } \\
& \text { MOIYL }+20 \% \text { Konsentrat }
\end{aligned}
$$

Tabel 1. Susunan ransum perlakuan

\begin{tabular}{lrrrr}
\hline Bahan Pakan & \multicolumn{4}{c}{ Perlakuan (\%) } \\
\cline { 2 - 5 } & \multicolumn{1}{c}{$\mathrm{P}_{2}$} & \multicolumn{1}{c}{$\mathrm{P}_{3}$} & \multicolumn{1}{c}{$\mathrm{P}_{4}$} \\
\hline Silase Komplit & 20,00 & 40,00 & 60,00 & 80,00 \\
Konsentrat: & & & & \\
Dedak Padi & 22,30 & 12,30 & 7,30 & 2,30 \\
Bungkil Inti Sawit & 30,00 & 25,00 & 15,00 & 5,00 \\
Bungkil Kedelai & 20,00 & 15,00 & 10,00 & 5,00 \\
Molases & 5,00 & 5,00 & 5,00 & 5,00 \\
Mineral & 1,00 & 1,00 & 1,00 & 1,00 \\
Garam & 0,50 & 0,50 & 0,50 & 0,50 \\
Urea & 1,20 & 1,20 & 1,20 & 1,20 \\
\hline Total & 100 & 100 & 100 & 100 \\
\hline
\end{tabular}

Tabel 2. Kandungan nutrisi ransum perlakuan

\begin{tabular}{lrrrr}
\hline Bahan Pakan & \multicolumn{4}{c}{ Perlakuan (\%) } \\
\cline { 2 - 5 } & \multicolumn{1}{c}{$\mathrm{P}_{1}$} & \multicolumn{1}{c}{$\mathrm{P}_{2}$} & \multicolumn{1}{c}{$\mathrm{P}_{3}$} & \multicolumn{1}{c}{$\mathrm{P}_{4}$} \\
\hline PK (\%) & 18,00 & 17,73 & 17,19 & 16,65 \\
SK (\%) & 15,92 & 16,62 & 17,16 & 17,70 \\
LK (\%) & 3,13 & 3,23 & 3,45 & 3,66 \\
TDN (\%) & 66,12 & 66,18 & 65,11 & 64,04 \\
\hline
\end{tabular}




\subsection{Parameter}

Parameter yang diamati meliputi:

a). Konsumsi ransum

Konsumsi ransum dihitung dengan cara menimbang jumlah pakan yang diberikan dikurangi dengan sisa pakan selama penelitian yang dinyatakan dalam g/ekor/hari dalam bentuk bahan kering.

Konsumsi Pakan= Pakan yang diberikan-Pakan yang sisa (g/ekor/hari)

b). Pertambahan bobot badan (PBB)

PBB merupakan selisih antar bobot badan awal dengan bobot badan akhir dibagi dengan lama pemeliharaan dinyatakan dalam g/ekor/hari.

c). Konversi pakan

Konversi pakan merupakan perbandingan antara jumlah konsumsi pakan dengan pertambahan bobot badan selama pemeliharaan dinyatakan dalam g/ekor/hari.

\subsection{Prosedur penelitian}

\subsubsection{Pembuatan probiotik MOIYL}

Probiotik MOIYL merupakan inokulum campuran (Cocktail inoculum) yang berasal dari mikroorganisme lokal yang diisolasi dari limbah perkebunan dan industri kelapa sawit yang terdiri dari Bacillus sp. YLB1, Trichoderma sp. YLF8 dan Saccharomyces sp. YLY3 [3] dan [4]. Proses pembuatan probiotik MOIYL dapat dilihat pada Gambar 1.

a) Peremajaan isolat bakteri, fungi dan yeast. Kultur murni sebelum digunakan perlu diremajakan. Peremajaan dilakukan pada medium agar miring NA, PDA dan MEA.

b) Pembuatan kultur starter. Masing-masing isolat diinokulasi pada media cair (NB, PDB, PDYB) secara aseptis lalu di gojog selama 72 jam.

c) Pembuatan kultur inokulan (inokulum campuran atau cocktail inokulum) modifikasi [4] meliputi 3\% dedak padi, 1\% urea, $0.5 \%$ pupuk sp-36, $1 \% \mathrm{t}$. ikan dan $0.5 \%$ terasi, $1.5 \%$ gula merah, $1.5 \%$ molases dalam 1.5 L air steril.

d) Medium perbanyakan kultur inokulan untuk fermentor (probiotik MOIYL)

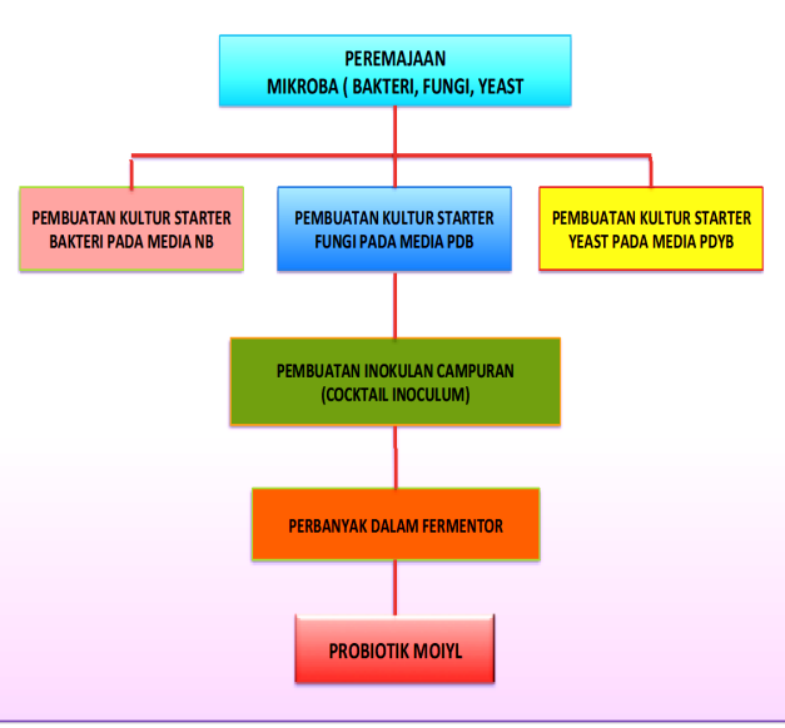

Gambar 1. Proses pembuatan probiotik MOIYL menggunakan cocktail inokulum [4]

2.5.2. Pembuatan silase komplit berbasis pelepah daun sawit dan indigofera sp. dengan probiotik MOIYL (Gambar 2)

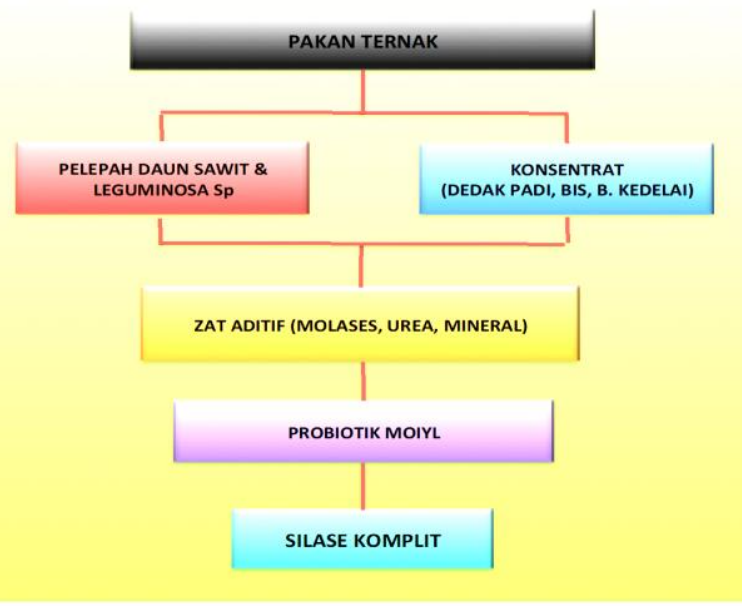

Gambar 2. Proses pembuatan silase komplit pelepah sawit dan indigofera $s p$.

\subsubsection{Persiapan kandang}

Kandang yang digunakan terlebih dahulu dibersihkan dan didesinfektan. Kandang yang digunakan adalah kandang individual dan semua peralatan yang digunakan seperti tempat pakan dan minum dibersihkan dan juga didesinfektan.

\subsubsection{Pemilihan ternak}

Penyeleksian ternak sapi yang digunakan sebagai objek penelitian melalui beberapa syarat sebagai berikut: ternak sapi dalam keadaan sehat dan tidak cacat dilihat secara fisik. Sebelum dimasukkan kandang sapi diukur bobot badannya terlebih dahulu untuk mengetahui bobot awal sapi tersebut. Lalu sapi dimasukkan ke dalam kandang individu. Sapi yang digunakan adalah sapi PO jantan umur 1,5 tahun dengan bobot badan awal 200,22+3,04 kg. 


\subsubsection{Pemberian ransum dan air minum}

Ransum yang diberikan adalah ransum perlakuan. Ransum perlakuan diberikan ad libitum. Sisa ransum yang diberikan ditimbang keesokan harinya untuk mengetahui konsumsi pakan ternak tersebut. Pemberian air minum diberikan secara tidak terbatas. Air minum diganti setiap hari dan tempatnya dicuci dengan air bersih.
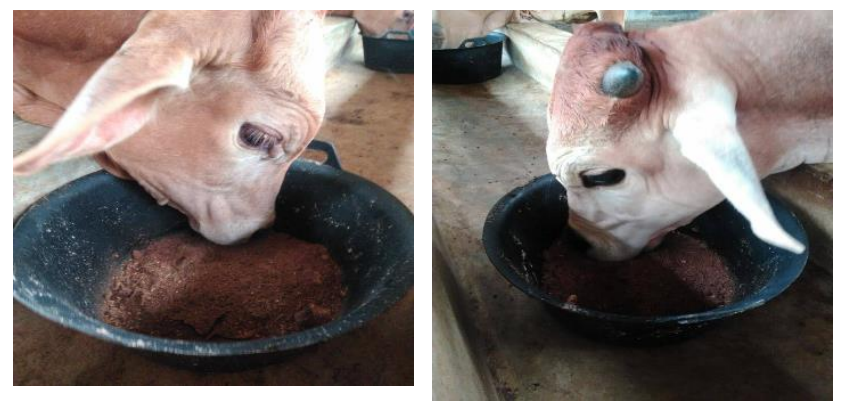

Gambar 3. Pemberian pakan silase komplit berbasis pelepah sawit dan indigofera

\section{Hasil dan Pembahasan}

Tabel 3. Konsumsi, PPB dan konversi sapi PO yang diberi ransum silase komplit berbasis pelepah sawit dan indigofera sp.

\begin{tabular}{cccr}
\hline \multirow{2}{*}{ Perlakuan } & \multicolumn{3}{c}{ Rataan Parameter } \\
\cline { 2 - 4 } & $\begin{array}{c}\text { Konsumsi } \\
\text { Ransum } \\
(\mathbf{g} / \mathbf{e} / \mathbf{h})\end{array}$ & $\begin{array}{c}\text { PBB } \\
(\mathbf{g} / \mathbf{e} / \mathbf{h})\end{array}$ & $\begin{array}{c}\text { Konversi } \\
\text { Pakan }\end{array}$ \\
\hline $\mathrm{P} 1$ & $6824,38^{\mathrm{B}}$ & $656,85^{\mathrm{B}}$ & $10,39^{\mathrm{C}}$ \\
$\mathrm{P} 2$ & $6823,36^{\mathrm{B}}$ & $640,37^{\mathrm{C}}$ & $10,66^{\mathrm{B}}$ \\
$\mathrm{P} 3$ & $6833,5^{\mathrm{A}}$ & $717,55^{\mathrm{A}}$ & $9,52^{\mathrm{D}}$ \\
$\mathrm{P} 4$ & $6791,21_{-}{ }^{\mathrm{C}}$ & $574,78^{\mathrm{D}}$ & $11,82^{\mathrm{A}}$ \\
\hline
\end{tabular}

\subsection{Konsumsi ransum}

Rataan nilai konsumsi ransum silase komplit pelepah sawit dan Indigofera sp. yang difermentasi dengan probiotik MOIYL bervariasi. Konsumsi ransum berkisar 6791,21 g/ekor/hari sampai 6833,51 g/ekor/hari atau 3-3.5\% kebutuhan bahan kering (Tabel 3).

Kemampuan sapi mengkonsumsi pakan sangat terbatas. Keterbatasan itu dipengaruhi oleh faktor ternak, keadaan pakan, dan faktor luar, seperti suhu dan kelembapan udara [5]. Kemampuan ternak untuk mengkonsumsi BK berhubungan erat dengan kapasitas fisik lambung dan saluran pencernaan secara keseluruhan [6].

Hasil analisis ragam menunjukkan pemberian silase komplit pelepah sawit dan leguminosa sp sampai $80 \%$ berpengaruh sangat nyata $(\mathrm{P}<0,01)$ terhadap konsumsi bahan kering sapi PO. Uji Duncan menunjukkan bahwa konsumsi ransum pada perlakuan $\mathrm{P}_{1}$ tidak berbeda nyata dengan perlakuan P2. Hal ini menunjukkan bahwa pemberian pakan silase komplit sampai level 40\% (P2) dalam ransum memberi respon konsumsi yang sama pada sapi yang diberi pakan silase $20 \%\left(\mathrm{P}_{1}\right)$. Namun, peningkatan konsumsi ransum terjadi seiring dengan peningkatan level pemberian (6o\%). Diduga terjadinya peningkatan konsumsi karena aroma ransum yang semakin wangi dan rasa asam sehingga turut mempengaruhi palatabilitas ransum. Akan tetapi, pemberian yang semakin tinggi (8o\%) menyebabkan konsumsi ransum menurun. Diduga penurunan palatabilitas disebabkan aroma ransum yang semakin tajam dan rasa yang semakin asam turut mempengaruhi konsumsi.

Disamping itu, kandungan serat kasar yang tinggi pada perlakuan $\mathrm{P}_{4}$ turut menyebabkan penurunan konsumsi ransum. Ini sesuai dengan pernyataan [4], bahwa perbedaan konsumsi bahan kering dipengaruhi palatabilitas ransum, semakin tinggi level pemberian produk fermentasi dalam ransum maka menyebabkan aroma semakin tajam dan rasa lebih asam sehingga mempengaruhi palatabilitas ransum. Disamping itu penurunan konsumsi yang dapat disebabkan komposisi nutrien yang berbeda terutama kandungan serat kasar. Kandungan SK yang tinggi menyebabkan laju fermentasi dalam rumen lebih lambat sehingga mempengaruhi laju pengosongan rumen yang berimplementasi terhadap konsumsi bahan kering.

Kemampuan ternak mengkonsumsi ransum dipengaruhi berbagai faktor seperti sifat fisik ransum (aroma, rasa dan tekstur pakan), dan kandungan nutrisi terutama kadar serat kasar dalam ransum.

\subsection{Pertambahan bobot badan}

Pertambahan bobot badan harian sapi selama penelitian berkisar 574,78 g/ekor/hari - 717,55 g/ekor/hari. Peningkatan bobot badan terjadi seiring dengan meningkatnya konsumsi ransum (Tabel 3). Konsumsi pakan merupakan faktor utama yang menentukan pertambahan bobot badan harian dari sapi [7].

Hasil analisis keragaman menunjukkan bahwa pemberian pakan silase komplit berpengaruh sangat nyata $(\mathrm{P}<\mathrm{O}, \mathrm{O1})$ terhadap pertambahan bobot badan pada sapi PO. Pertambahan bobot badan harian sapi meningkat seiring dengan peningkatan konsumsi ransum. Konsumsi yang meningkat terjadi karena peningkatan level pemberian pakan silase. Pakan silase dengan probiotik MOIYL disamping menghasilkan pakan mudah dicerna oleh mikroba rumen, pakan juga bersifat probiotik karena mengandung bakteri penghasil asam laktat.

Probiotik adalah mikroba hidup dalam media pembawa yang menguntungkan ternak karena: menciptakan keseimbangan mikroflora dalam saluran pencernaan sehingga menciptakan kondisi yang optimum untuk pencernaan pakan dan meningkatkan efisiensi konversi pakan sehingga 
memudahkan dalam proses penyerapan zat nutrisi ternak, meningkatkan kesehatan ternak, mempercepat pertumbuhan, memperpendek jarak beranak, menurunkan kematian pedet, dan memproteksi dari penyakit patogen tertentu sehingga dapat meningkatkan produksi susu atau daging [8].

Hasil uji duncan menunjukkan bahwa perlakuan $\mathrm{P}_{4}$ sangat berbeda nyata $(\mathrm{P}<\mathrm{O}, \mathrm{O} 1)$ dengan $\mathrm{P}_{1}, \mathrm{P}_{2}$ dan $\mathrm{P}_{3}$. Perlakuan $\mathrm{P}_{3}$ menunjukkan perbedaan dengan kenaikan angka rataan pertambahan bobot badan yang lebih baik, sehingga pemanfaatan pelepah sawit dan legum indigofera yang dibuat silase dengan tambahan probiotik MOIYL dapat di gunakan sebagai pakan ternak sapi. Hal ini terlihat dari perlakuan $\mathrm{P}_{3}$ (6o\% silase komplit dengan MOIYL + 40\% konsentrat) dengan angka $\mathrm{PBBH}$ tertinggi yaitu sebesar 717,55 \pm 3,92. Hal ini sesuai dengan pernyataan [9] yang menyatakan bahwa faktor pakan sangat menentukan pertumbuhan, bila kualitas pakan baik dan diberikan dalam jumlah cukup, maka pertumbuhan akan semakin cepat dan sebaliknya bila kualitas pakan jelek dan diberikan dalam jumlah yang kurang, maka pertumbuhan akan menjadi lambat.

Pertambahan bobot badan harian terendah terdapat ada perlakuan $\mathrm{P}_{4}$ yakni $574,78+3,85$ g/ekor/hari (Tabel 3). Sapi PO dalam kondisi pemeliharaan biasa dapat menghasilkan pertambahan bobot badan hingga o,6 kg/hari. Rendahnya pertambahan bobot badan ternak ini lebih banyak disebabkan oleh faktor lingkungan, yaitu pemberian pakan yang tidak memadai dan jumlahnya tidak mencukupi dari kebutuhan [10]. Dimana palatabilitas ternak dalam mengkonsumsi ransum mempengaruhi jumlah pakan yang dikonsumsi dan juga berpengaruh pada laju pengosongan rumen. Bau asam yang tinggi pada pakan perlakuan $\mathrm{P}_{4}$ menurunkan palatabilitas sehingga menurunkan tingkat konsumsi yang berbanding lurus dengan tingkat pertambahan bobot badan yang rendah

Hasil penelitian menunjukkan pada perlakuan $\mathrm{P}_{1}$ peningkatan bobot badan relatif lebih rendah dibandingkan dengan perlakuan $\mathrm{P}_{3}$ dimana adanya respon negatif terhadap tingkat protein yang tinggi. Hal ini sesuai dengan pernyataan dari [11] yang menyatakan bahwa pertambahan bobot badan pada ternak tidak hanya merupakan fungsi deposisi protein, melainkan juga merupakan fungsi deposisi lemak. Selain itu, dalam beberapa waktu tertentu (pada perlakuan $\mathrm{P}_{1}$ ) kandungan protein yang tinggi kurang baik untuk kesehatan ternak. Hal ini terlihat dari ternak yang berada pada perlakuan $\mathrm{P}_{1}$ mengalami gangguan pencernaan (diare) sehingga pertambahan bobot badan tidak lebih baik dibanding perlakuan lainnya.

\subsection{Konversi ransum}

Konversi ransum sapi PO yang diberi pakan silase komplit pelepah sawit dan indigofera sp dengan probiotik MOIYL berkisar 9.52 - 11,82 (Tabel 3). Hasil konversi ransum penelitian ini relatif lebih baik dibanding penelitian [12] yaitu mencapai nilai 13,29. Tinggi rendahnya konversi ransum menggambarkan keefisienan ransum dimana semakin rendah konversi ransum maka semakin efisien ransum tersebut [4].

Hasil analisis keragaman menunjukkan bahwa pemberian pakan silase komplit berpengaruh sangat nyata $(\mathrm{P}<\mathrm{O}, 01)$ terhadap konversi pakan pada sapi $\mathrm{PO}$. Konversi pakan sangat dipengaruhi oleh kondisi ternak, daya cerna, jenis kelamin, bangsa, penyakit, kualitas dan kuantitas pakan, juga faktor lingkungan yang tidak kalah penting [13].

Perbedaan angka tersebut dipengaruhi oleh pertambahan bobot badan dan konsumsi. Nilai konversi menunjukkan efisien penggunaan pakan. Hal ini sesuai pernyataan dari [14], yang menyatakan bahwa konversi pakan adalah indikator teknis yang dapat menggambarkan tingkat efisiensi penggunaan pakan, semakin rendah angka konversi pakan berarti semakin efisien. Hasil penelitian menunjukkan bahwa perlakuan $\mathrm{P}_{3}$ memiliki angka konversi pakan terendah dibanding perlakuan lainnya. Nilai konversi yang rendah menunjukkan angka penggunaan pakan yang efisien pada perlakuan tersebut.

Berdasarkan hasil uji duncan diketahui bahwa $\mathrm{P}_{1}$ sangat berbeda nyata $(\mathrm{P}<0,01)$ dengan $\mathrm{P}_{2}, \mathrm{P}_{3}$ dan $\mathrm{P}_{4}$. Nilai konversi pakan juga dipengaruhi oleh kualitas pakan dan palatabilitas. Kedua faktor tersebut merupakan salah satu faktor utama penentu tinggi rendahnya nilai konversi. Hal ini sesuai dengan pernyataan dari [15], yang menyatakan bahwa kualitas pakan menentukan konversi pakan. Pakan yang berkualitas baik dapat menghasilkan pertambahan bobot badan yang tinggi. Penggunaan pakan akan semakin efisiensi bila jumlah pakan yang dikonsumsi minimal namun menghasilkan pertambahan bobot badan yang tinggi.

Keberadaan probiotik MOIYL pada pakan silase komplit mendukung efisiensi penggunaan pakan karena memiliki kemampuan untuk mendegradasi karbohidrat seperti selulosa dan hemiselulosa yang memang sulit dicerna dan menunjang pengurangan penggunaan konsentrat yang pada umumnya memerlukan jumlah yang banyak dan harga yang mahal.

\section{Kesimpulan}

Silase komplit berbasis pelepah kelapa sawit dan Indigofera sp. menggunakan probiotik MOIYL dapat meningkatkan konsumsi ransum, pertambahan bobot badan pada sapi dan menurunkan konversi ransum. Penggunaan silase komplit yang semakin tinggi mampu menurunkan penggunaan konsentrat seperti 
dedak padi, bungkil inti sawit dan bungkil kedelai yang berpengaruh terhadap efisiensi penggunaan pakan ternak.

\section{Referensi}

[1] Mathius, I. W., D. Sitompul, R. J. Manurung dan Aani. 2003. Produk Sampah Tanaman dan Pengolahan Buah Kelapa Sawit sebagai Bahan Dasar Pakan Komplit untuk Sapi: Suatu Tinjauan. Prosiding Lokakarya Sistem Integrasi Kelapa Sawit Sapi. Bengkulu. 9-10. September 2003. Departemen Pertanian Bekerjasama dengan Pemerintah Provinsi Bengkulu dan Agricinal.

[2] Krisnan, R., J. Sirait, A. Tarigan, K. Simanuhuruk. 2012. Indigofera sebagai Pakan Ternak. Pusat Penelitian dan Pengembangan Peternakan. Badan Litbang Pertanian. Kementerian Pertanian. IAARD Press.

[3] Yunilas, L. Warly, Y. Marlida, dan I. Riyanto. 2013. Potency of Indigenous Bacteria from Oil Palm Waste in Degrades Lignocelluse as a Sources of Inoculum Fermented to High Fibre Feed. Pakistan Journal of Nutrition 12 (9):851853.

[4] Yunilas. 2016. Aplikasi Bioteknologi Dalam Pengolahan Pakan Komplit Menggunakan Mikroba Indigenous Berbasis Limbah Perkebunan Dan Industri Kelapa Sawit Sebagai Pakan Ternak Ruminansia. Disertasi. Program Pascasarjana, Universitas Andalas, Padang.

[5] Sarwono, B. dan H. B. Arianto. 2001. Penggemukan Sapi Potong Secara Cepat. Penebar Swadaya. Jakarta

[6] Haryanti, N. W. 2009. Kualitas Pakan dan Kecukupan Nutrisi Sapi Simental di Peternakan Mitra Tani Andini, Kelurahan Gunung Pati, Kota Semarang. Jurusan Nutrisi dan Makanan Ternak Fakultas Peternakan Universitas Diponegoro Semarang.

[7] Wasdiantoro, H. 2010. Imbangan Hijauan dan Konsentrat yang Berbeda pada Penampilan Produksi Sapi Sumba Ongole yang Diberi Tiga Macam Ransum Penggemukan. Skripsi. Fakultas Peternakan IPB, Bogor.

[8] Novianto, W. A, Sarwiyono dan E. Setyowati. 2013. Penampilan Produksi, Kadar Protein dan Kadar Lemak Susu Sapi Perah Peranakan Friesian Holstein yang Diberi Pakan Tambahan Probiotik. Fakultas Peternakan Universitas Brawijaya, Malang.

[9] Dinata, F. F., R. Adiwinarti Dan W.S. Dilaga. 2009. Pertumbuhan Sapi Peranakan Ongole (Po) Akibat Pemberian Level Konsentrat yang Berbeda. Fakultas Peternakan Universitas Diponegoro, Kampus Tembalang, Semarang
[10] Wiyatna, M. F., E. Gurnadi dan K. Mudikdjo. 2012. Produktivitas Sapi Peranakan Ongole pada Peternakan Rakyat di Kabupaten Sumedang. Fakultas Peternakan IPB. Bogor.

[11] Alim, H. 2014. Pertambahan Bobot Badan Kambing Marica Jantan dengan Pemberian Pakan Komplit pada Taraf Protein yang Berbeda. Program Studi Produksi Ternak Fakultas Peternakan Universitas Hasanuddin, Makassar.

[12] Siregar, S.B. 2008. Penggemukan Sapi. Penerbit Swadaya. Jakarta.

[13] Rosida, I. 2006. Analisis Potensi Sumber Daya Peternakan Kabupaten Tasikmalaya Sebagai Wilayah Pengembangan Sapi Potong. Fakultas Peternakan Institut Pertanian Bogor.

[14] Sianipar, T. P. 2009. Efek Pelepah Daun Kelapa Sawit dan Limbah Industrinya sebagai Pakan Terhadap Pertumbuhan Sapi Peranakan Ongole pada Fase Pertumbuhan. Program Studi Peternakan Fakultas Pertanian Universitas Sumatera Utara. Medan.

[15] Simanjuntak, S.M., Yunilas dan Tafsin, M. 2015. Fermentasi Hasil Samping Industri Dan Perkebunan Kelapa Sawit Dengan Probiotik Lokal Terhadap Performans Domba. Jurnal Peternakan Integratif Vol. 4 No.1 Desember 2015: 83-95. 